\title{
Ibadism and law in historical contexts
}

OÑATI SOCIO-LEGAL SERIES VOLUME 10, ISSUE 5 (2020), 960-984: HistORICAL AND COMPARATIVE

MACROSOCIOLOGY OF MIDDLE EASTERN LEGAL SYSTEMS

DOI LINK: HTTPS://DOI.ORG/10.35295/OSLS.IISL/0000-0000-0000-1155

RECEIVED 23 NOVEMBER 2018, ACCEPTED 08 MAY 2020

\section{KNUT S. VIKØR*}

\section{Abstract}

Not Sunnis and not Shi'is, the Ibādị Muslims of Oman and some areas of North Africa form a "third branch" of Islam, with their own version of the Shari'a law. The development of this law displays many interconnections with the political history of the Ibādīs, which spanned from an independent sultanate in Oman, through minority status under Sunni rule in Tunisia and Libya, to isolated desert communities in Algerian Sahara. This article gives an overview over such interconnections between the political (state authority) and the legal, through history and in contemporary North Africa, with some examples of legal discussions from the "Ibādī renaissance" (nahḍ) in the twentiethcentury Saharan oasis of Mzab.

\section{Key words}

Ibāộ̄ law; Oman; Algeria; Sharī‘a

\section{Resumen}

Ni suníes ni chíes, los musulmanes ibadíes de Omán y de algunas zonas del norte de África forman una "tercera rama" del Islam, con su propia versión de la ley de la sharía. El desarrollo de esa ley expone muchas interconexiones con la historia política de los ibadíes, la cual abarcó desde un sultanato independiente en Omán, pasando por ser una minoría bajo el dominio suní en Túnez y Libia, a comunidades aisladas en el desierto del Sáhara en Argelia. Este artículo hace un repaso de dichas interconexiones entre lo político (autoridad estatal) y lo jurídico, a través de la Historia y en el Norte de África en la actualidad, con algunos ejemplos de debates jurídicos sobre el "renacimiento ibadí" (nahḍ) en el oasis del Sáhara del siglo XX de Mzab.

\footnotetext{
This article is a preliminary survey that outlines some directions for future research on modern Ibāḍ̄ law. Any conclusions in it must therefore be considered tentative only at this stage. I thank the organizers for allowing me to present it to the Oñati workshop in June 2018.

* Knut S. Vikør. University of Bergen. Postboks 7805. 5020 Bergen, Norway. Email address: knut.vikor@uib.no
} 


\section{Palabras clave}

Derecho ibadí; Omán; Argelia; sharía 


\section{Table of contents}

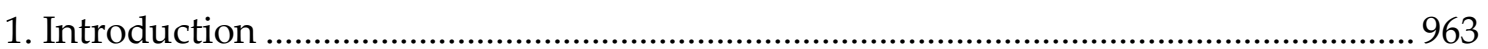

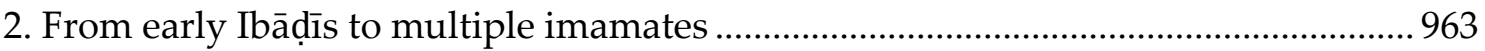

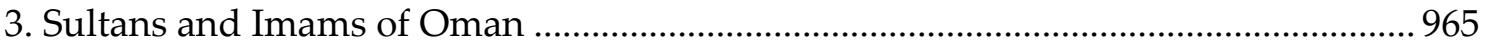

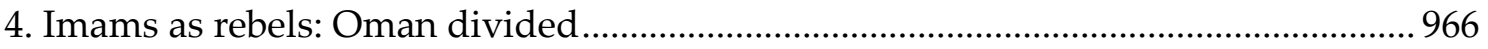

5. The Maghreb: independent and subordinate minorities........................................... 968

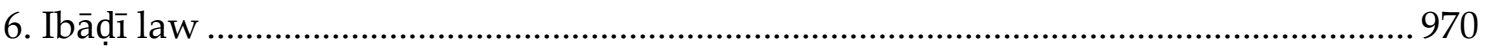

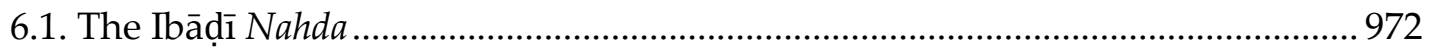

6.2. A reformist view on marriage? Bayyūẹ on zawāj ............................................ 975

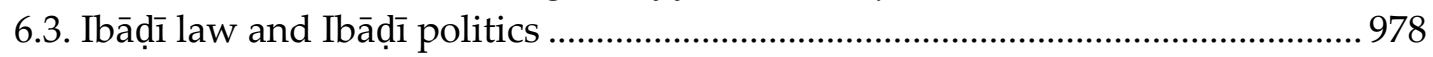

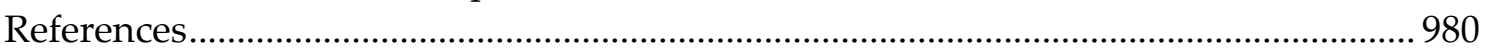




\section{Introduction}

In a Muslim world dominated by increasing tension between Sunnis and Shi'is, the small minority that is neither Sunni nor Shi'i tries to stay out of the conflicts, and emphasizes their neutral stance of being friends to all and enemies to none. This may seem ironic in the sense that this group of Ibādīs are historically linked to the ferocious Khawārij, the violent extremists of early Islam, a name that the extreme jihādī groups like IS use to brand those they consider to be even more extreme than themselves (al-Misri 2000, Kenney 2006). Not true, say the Ibāḍis, we have nothing to do with the Khawārij, those who are called that strayed from the true path of our forbears who peacefully left the battle of Șiffin. We agree with them, they say, that only the pious (meaning the Ibādīs themselves) are actually Muslim, and those others who claim to be Muslims are in fact all sinners bound for Hell, but this is only a theological viewpoint (Hoffman 2012, 2015; see also Bayyūḍ 1971, pp. 37-52, and Țallāy 1996). Legally, these non-Ibāḍis, the ahl alqibla ("those who pray towards Mecca"), though hypocrites, are to be treated as Muslims (even if they are not), we can trade with them, eat their food, and even, under certain circumstances, marry them, and should not as the "Khawārij" claimed, fight and kill them.

Whether it is just due to their marginality or to this unclarity over who is legally a Muslim and thus subject to the Sharī'a, Ibādī law has largely escaped the attention of historians of Islamic law. Many have no doubt been deterred by Josef Schacht's somewhat offhand remark that Ibāḍi law was merely developed on the basis of the later Sunni madhhabs (Schacht 1950, p. 261). In the last few years, a greater interest has developed, trying to identify some specificities of Ibādī law as being outside both the Sunni and the Shi'i traditions. It is for example interesting that Ibādī law constitutes one unified legal tradition, even though Ibāḍ̄ communities today live in political circumstances that are diametrically opposite: On the one hand, as rulers of a sultanate in Oman, on the other, as tiny minorities in marginal areas in the Maghreb. Even more surprising is that it is often the latter small groups that spearheaded the legal developments that was also authoritative in the east.

As the history, or indeed existence, of this current of Islam and its legal history is mostly unknown to others than those who specialize in it, we will in this modest contribution give an introductory overview of the political and legal regimes that Ibādī communities have lived under throughout its history, and illustrate it with a some legal opinions on family law from the Ibādī nahḍa, "revival" in twentieth century Maghreb, thus looking at the relation between legal discourse and community in the modern period.

\section{From early Ibāḍis to multiple imamates}

The connection between today's Ibādīis and the early extremist Khārijīs of the late seventh century is thus contested, as is the origin of the Ibādì current itself (Ennami 1971, Cuperly 1991, pp. 13-30, Madelung 2006, Mu'ammar 2007, Wilkinson 2010). The Ibādīs accept that they are linked to the group that left the caliph 'Alī b. Abì Țâlib's side at the crucial battle of Siffin in 657, many of whom were subsequently massacred by 'Ali's troops at Nahrawān in the following year. According to their own narrative, the founder of the Ibādì branch was the Omani scholar Jābir b. Zayd al-Azdī (d. 712), who was known both as a legal scholar, faqīh, and a collector of Prophetic traditions, hadìth. Both Jābir's 
position as "first imām" and author of the hadith collection that carries his name has been challenged by modern scholars such as John Wilkinson (1985, 1987, pp. 153-60, 2010, pp. 154-210) but there seems to be agreement on that in the course of the eighth or ninth century, a group of scholars came into being, primarily in Bașra in Iraq, who shared a number of legal and theological opinions and eventually came to be recognized under the name of Ibādīs. ${ }^{1}$

While it is uncertain how distinct this group was from the general class of scholars in Bașra at Jābir's time, the Ibāḍ̄ narrative speaks of increased oppression from the new masters of Iraq after the Abbasid revolution in 750. While leading scholars remained behind in Bașra for a while longer, other Ibādīis withdrew to Oman, which had been Jābir's region of origin. They established an Ibāḍ̄i imamate there in 793 based on support from the local tribes (Wilkinson 1987, al-Rawas 2000, Prevost 2010, pp. 9-16).

What primarily set the Ibādīs apart, was the issue of political leadership of the Muslim community, the imamate. While both Sunnis and Shi'is make genealogy in one form or another a prerequisite for an imām (caliph), the Ibāḍis reject this, and only accept competence - where piety is an important element, but also the ability to gain acceptance and to rule - as the criterion for a just ruler (Wilkinson 1987, p. 168, Gaiser 2010). ${ }^{2}$ The imamate seems never to have been exclusive, alongside the early Oman imamate there were at least two others at the same time, each recognizing the others as governing over a separate mișr (polity): one in Hadrramawt in Yemen (from ca. 745) (Lewicki 1971, pp. 651-3, Prevost 2010, pp. 8-10, Hoffman 2012, p. 13) and one in the Maghreb.

It was the latter that was most important, and it was the largest Ibādī power we have ever seen. By the eighth century, a large part of the populations of North Africa, still almost exclusively Berber, had accepted Islam. It seems that some had encountered Ibādī thought either from travellers to the Maghreb or by visiting Iraq already at the turn of the eighth century, ${ }^{3}$ since some Berber leaders came to Bașra at the time of the second Ibāḍ̄i imām, Abū 'Ubayda b. Abī Karīma al-Tamīmī. ${ }^{4}$ Urged or inspired by them, Abū 'Ubayda sent a hamalat al-ilm, a missionary expedition to the Maghreb in 757. It consisted of an Arab, Abū 'l-Khațtāb al-Ma'āfirī who assumed command of the group, three Berber leaders, and a Tunisian of Persian origin, 'Abd al-Rahmān b. Rustam. On arrival in Tripolitania, Abū 'l-Khātțāb was quickly elected imām by the Berber tribes, and raised a revolt that conquered much of Tunisia and Tripolitania, appointing Ibn

\footnotetext{
${ }^{1}$ The Khārijī rebels who gave them such a bad name, were according to the Ibādīs a separate offshoot of the Nahrawān survivors, led by Nāfī ' b. Azraq (d. 685), who for a short period of time carried out a number of revolts from their base in south-western Iran, and were criticized for their murderous extremism by the early Ibādī leaders (Lewinstein 1991, pp. 251-68). The Bașra group does not seem to have showed any political ambition while still living in that city. Why they were called "Ibādīis" is contested, but may refer to an early scholar, 'Abd Allāh Ibn Ibāḍ, who is, however, not considered an imām by most Ibāḍīs.

2 The expression, the best "be he an Ethiopian slave" is however incorrectly attributed to them, according to Patricia Crone (1994, pp. 59-67).

3 Traditionally, the first Ibādī missionary to go the the Maghrib was the Bașran Salma b. Sa îd, who accompanied a mission of Șufrīs, another branch of Khārijīs, before 720 (Lewicki 1971, p. 633). That of course assumes that Ibāḍism and Șufrism actually existed as clear identities this early. Lewicki accepts widespread control of Ibāọīs in Tripolitania even before the hamalat al- 'ilm of Abū 'l-Khațāa (Lewicki 1957, pp. 301-343). ${ }^{4}$ By "imām", whether Abū 'Ubayda used the title or not, must most certainly have been meant only the leader of the group of scholars in Bașra that identfied as Ibāḍì, not any political leadership. His year of death is not known, but probably before 775 .
} 
Rustam to be governor of the latter's native Qayrawān. It did not last long, however, before the Abbasid forces pushed them back, and Abu 'l-Khātțāb was killed in 761. Ibn Rustam withdrew westwards to what is now western Algeria, and established a town at Tahert, which soon became an important trading centre. In 776, the Berbers there proclaimed him imām al-zuhūr, which means that as "apparent" or "established" imām, he had a higher religious authority that the former "struggling imām" (imām al-shirā', imām al-difā ). ${ }^{5}$ His Rustamid state expanded to dominate much of the Maghreb, from eastern Morocco to western Libya in today's terms, until the Shi'i Fatimids swept through the region in 909. There were however also other Ibādī statelets on the fringes of or outside Rustamid control in the Maghreb, as well as states (like the important trade city of Sijilmāsa in Morocco) dominated by the related Șufrīya brand of "Khārijism". Thus most of North Africa west of Egypt was in Ibādīi or related hands throughout the ninth century.

At the time of the Rustamid collapse in 909, the two other Ibāḍi imamates had also disappeared, the Hadramī one for good, ${ }^{6}$ while the Omani imamate broke down in internal conflict and was conquered by Abbasid forces from 893. Oman did however retain an Ibādị identity and was able to free itself from direct Abbasid control, but the civil war had split the country, and while some leaders in the interior seem to have used the title of imām until the twelfth century, they did not command general authority, and little is known about this period of Omani history. Only from 1615 was a unified imamate reestablished under the Ya rūbī clan (Ghubash 1998, pp. 88-107).

\section{Sultans and Imams of Oman}

After the initial heyday of the ninth century, the largest community of Ibādīis was, and remains, clearly the one in Oman. Ibādī identity had become deeply entrenched there. However, it seems also to have integrated into tribal identity, and the leading historian of the Omani Ibāḍīs, John Wilkinson (1987, passim), sees the adoption of Ibādism there primarily through the tribal framework. This may help explain why, due to tribal fractionality, there was no unified imām in the long period from the tenth to the seventeenth century, but also the form it reappeared in. As we have noted, the most important argument of the early Khawārij-cum-Ibādīs was that the position of imām should go to the most competent Muslim without regard for genealogy. The imām was to be elected freely by the most prominent scholars, the ahl al-hall wa'l- 'aqd.

Nevertheless, when the imamate reappeared with the Ya rübids in the seventeenth century, it was clearly dynastic: the imamate followed a family line, and the committee of binders and losers only confirmed the genealogical selection. ${ }^{7}$ The same applied when the Ya rūbids in 1741 gave way to the Bū-Sa $\overline{1} d \overline{1}$ dynasty, power followed a largely patrilineal line. The new Bū-Sa'îdī imamate only lasted half a century, however, until the death of imām Ahmad b. Sa'īd al-Bū-Sa'īdī in 1783. Two of his sons vied for leadership. The elder, Sa'īd b. Ahmad was elected imām, but was challenged by his

\footnotetext{
${ }^{5}$ Gaiser (2010) has a thorough discussion of the various types, or levels, of imām.

${ }^{6}$ Lewicki says that there was an imamate in Hadramawt until the second half of the eleventh century, but that seems to have been a small residual group (Lewicki 1971, p. 652).

7 The second Ya 'rūbī imām, Sulțān b. Sayf (1649-88), was the cousin of his predecessor, but Sulțān was succeeded by his sons Bel'arab (1688-92) and Sayf (1692-1711), then the latter's son Sultān b. Sayf II (Ghubash 1998, pp. 93-7).
} 
brother Sulțān b. Aḥmad who had gained legitimacy from repelling a Persian invasion. Sultạn controlled the coast, with the town Masqat as his capital, while Sa 'īd remained in the traditional Ibādī capital of Nizwā in the interior. A modus vivendi was established between the brothers, where Sa 'îd remained imām, while Sulțān was the actual ruler, with the title of sultan. ${ }^{8}$ When Sa $\overline{1} \mathrm{i} d$ died after $1790,{ }^{9}$ no successor imām was appointed, and the Bū-Sa 'îdī ruler of Masqat was the sole master of the country as sultan of Oman, and has remained so until the present incumbent, Sultan Haytham al-Bū-Sa ${ }^{\prime} \mathbf{i} \overline{1}$.

Over the last centuries, the demography of the sultanate has changed. While the earlier imāms ruled a country that was probably either exclusively Ibādī, or they had a clear dominance, conversions, population movements and expansion to modern national borders have created a state where Ibāḍīs co-exist with non-Ibāḍīs (mainly Shāfi 'î Sunnis, but also Shi'is and other communities). No census has ever been taken to establish the exact balance between the groups, thus estimates can be found both that Ibādīis constitute half the population, somewhat less than half, or up to a three-quarter majority. ${ }^{10}$ It is probably most prudent to say "about one half". However, the geography is fairly clear: Ibādīis dominate in the inland tribal regions, some of which may (at least until recently) have remained exclusively Ibādī, while the coastal regions, as well as the large Dhofar province in the south (exclusively Sunni) has large groups of Shāfi 'i Sunnis with the smaller minorities. Thus, Oman is a state governed by an Ibādī ruler, but where Ibādīs co-exist with other Muslim groups.

\section{Imams as rebels: Oman divided}

This sultanic system has been challenged by imamate revolts twice in the last two centuries. The first took place in 1868. The sultanate had then gone through serious upheavals that had led sultan Sa'ìd b. Sultān (ruled 1806-56) to move the Omani capital away from Oman to Zanzibar in East Africa in 1832 (Ghubash 1998, pp. 161-79, Pouwels 2002, pp. 97-124, Jones and Ridout 2015, pp. 50-70). Omanis had spread Ibādism to the Indian Ocean seaports of East Africa over a number of centuries, and several city-states had been ruled by local Ibādīs of Arab origin. With increased Omani strength, the sultanate came to control much of East Africa, and it became an economic engine for the state. Omanis had over time moved back and forth between the homeland and the East African cities, and Zanzibar had by the nineteenth century grown to become the most important political centre. Thus, it was not so illogical as it might seem that the sultan wanted to make the city the centre of his Indian Ocean empire.

But many opponents within his family used his absence to rid themselves of rival pretenders, and when sultan Sa 'īd died in 1856, one of his sons, Thuwaynī, was declared sultan in Masqat, while another, Mäjid, became sultan in Zanzibar. The British, now an important actor both in East Africa and in South Arabia, supported and negotiated this division of the empire into two states. This was thus the background for the imami rebellion in Oman twelve years later in 1868 (Ghubash 1998, pp. 180-207, Jones and

\footnotetext{
8 Thus sultan Sulțān, the title is confusingly also a quite common personal name in the region.

${ }^{9}$ Dates of his death vary from 1790 to early 1820 s (Wilkinson 1987, p. 227).

10 According to Encyclopaedia Britannica (academic.eb.com, "Oman"), the Ibādī branch "claims the most adherents", while Encyclopedia of Islam says that a small majority is Sunni (EI (2), Supplement, 819 [J.E. Peterson]). Wikipedia says "three quarters" ("Islam in Oman"), while CIA World Factbook diplomatically says Sunnis and Ibāẹ̄is "each constitute about 45\%", with 5\% Shi'i.
} 
Ridout 2015, pp. 75-80). The revolt was raised by the scholar Sa 'īd b. Khalfān al-Khalīlì, but he appointed a relative of the sultan, 'Azzān b. Qays al-Bū-Sa'īdì, as imām. The new imām was thus of the same family as the sultan, but from a rival branch. ${ }^{11}$ With British support, however, the revolt was quashed and imām 'Azzān killed in 1871.

Forty years later, in 1913, many of the scholars who had been behind 'Azzān tried again, and this time with more success (Ghubash 1998, pp. 234-80, Jones and Ridout 2015, pp. 112-30). They installed Sālim b. Rāshid al-Kharūṣī as imām. Unlike 'Azzān, he was not a Bū-Sa 'īdī, but from the influential Kharūṣī tribe which had provided Oman with many scholars over the centuries. When imām Sālim was murdered in 1920, his replacement, Muhammad b. 'Abd Allāh al-Khalīlī was not a relative. He was, however, the grandson of Sa 'īd b. Khalfān, who had been the scholar behind the 1868 revolt.

The imamate forces were able to force the sultan to a compromise. They reached a settlement in the treaty of Sïb in 1920, negotiated with the help and at the instigation of the British, who were in reality the main force behind the sultan.

Under this agreement, Oman was to remain one country, but with two political systems (Wilkinson 1987, pp. 249-328). The imām was recognized in Nizwā in the interior, while the sultan continued to rule from Masqat on the coast. In reality, the regions were largely independent from each other and each ruler saw himself as the master of the other: The imām assumed that as imām, he had appointed the sultan to rule one region of his country, while the sultan considered the imām as a purely religious figurehead, allowed to administer the interior. The British supported the latter view, thus the sultan was internationally recognized as the ruler of Oman. But the two were sometimes treated as two different entities, thus the "imamate of Oman" (the interior) and the "sultanate of Muscat" (the coastal region as well as Dhofar). The imām and his people did not worry about this lack of international recognition, as the imamate isolated itself almost completely from the external world (Jones and Ridout 2015, pp. 99-112). ${ }^{12}$ At one point, however, the imamate did also issue passports in its own name, and thus presented itself as an independent polity (Wilkinson 1987, p. 314).

This situation of "two countries in one" lasted until imām Muhammad died in 1954. The council of 'ulamā' al-kabìr elected Ghālib b. 'Alī al-Hinawì to replace him, thus again promoting tribal power-sharing over dynastic practice. The sultan did not oppose this selection. However, he used the occasion to change the situation on the ground, and in a coup sent forces against the imamate. Nizwā was occupied in December the following year (Jones and Ridout 2015, p. 199). Imām Ghālib fled, but maintained a guerrilla war against the sultan with some support from Saudi Arabia. Although they briefly reconquered Nizwā in 1957-9, their resistance petered out by the early 1960s. ${ }^{13}$ So in effect, the imamate-state lasted from 1920 to 1954.

As we can see from the religious geography above, the two half-states had different compositions. The imamate controlled the tribal regions of the interior and was thus dominantly Ibāḍ̄i They could practice Ibāḍi politics and Ibāḍ̄ law if they so wanted. The

\footnotetext{
${ }^{11}$ He was a grandson of the first Bū Sa 'īdī imām, Aḥmad b. Sa'īd.

12 The sultan too shut his part of the country off and opposed almost any kind of modernization, only the British were allowed the presence it needed to shore up his state and preserve their interests.

${ }^{13}$ The effective struggle ended in 1965. Ghālib died in 2009, at the age of 96.
} 
sultan's areas included most of the heterogeneous parts of Oman, with a larger element of non-Ibādịis, like the unified Oman of today. ${ }^{14}$

Oman remained closed to the outside world (British excepted) after unification, with the sultan himself withdrawing to his palace in Dhofar. It was only when his son Qābūs (d. 2020) deposed his father in a coup in 1970, that an accelerated process of modernization began. Oman now presents itself as a non-sectarian sultanate, free from Shi'i-Sunni division, while at the same time being proud of its Ibādī heritage and spending considerable sums on promoting scholarship on its Ibāḍi past (Prevost 2010, pp. 26-8, Broucek 2018).

\section{The Maghreb: independent and subordinate minorities}

In the Maghreb, the Ibādīis constitute a much smaller minority. While Oman has a population of some four million, thus a guestimate of 2-2,5 mill. Ibādīis, the total number of Ibādīs in the Maghreb is probably in the region of 200,000. The Maghrebi community was scattered and fragmented by the Fatimid expansion, and they went mainly in three different direction: The largest group withdrew southwards into the desert, where they could escape the power of the expanding Fatimid, and later Sunni dominance (Savage 1997, pp. 137-46, Prevost 2010, pp. 32-7). Another group had already settled in Jerba Island, today in southern Tunisia, where they remained a dominant part of the population. A third withdrew into the countryside in the Nafzāwa and Jarīd regions of Tunisia, where they successively died out, ${ }^{15}$ as well as to the Jabal Nafüsa mountains in Tripolitania. The latter community survived, and is also present in the Zouara region of coastal Libya (Dbeez 2017, pp. 60-8). All Maghrebi Ibāḍīs retained a Berber (Amazigh) identity throughout the process of Arab migration and Arabization of Berbers from the tenth century on - far from all Berbers are Ibāḍī (only a tiny minority of them are) but all Ibādīis in the Maghreb are Berber.

Retreating into the Sahara was a fairly natural thing for the Ibādịs, as they had in their heyday largely built their fortune on the trans-Saharan trade and had established trading communities both in desert oases on the trade routes, and across the Sahara in West Africa (Lewicki 1960, 1962, 1964). Some regions were so remote that the escaping Ibādīs could even establish their own small states, thus the desert-side region of Fezzan (now the south-western quarter of Libya) was ruled by an Ibāḍi dynasty, the Banū Khātțāb, all the way from 918 until 1176 (Lavers 1979 [Fazzan: Sudanic or Saharan state? Unpublished paper, on file with author], Vikør 1999, pp. 153-61). During this period, Ibādī traders could continue to practice their trans-Saharan trade, although sources also tell of Arab (and thus Sunni) traders sharing in the commerce in this period. ${ }^{16}$

\footnotetext{
${ }^{14}$ This is not completely clear-cut, as the borders were not quite rigid. There was thus considerable pressure from Saudi Arabia against the borders of the imamate, and attempts to convert tribes in the marginal areas to Wahhabism, not least in the Buraimi oasis region to the north, which ended up being part of the United Arab Emirates. Thus, the exact division between Ibāḍ̄is and non-Ibādīis, Wahhābī or Shāfi 'î in these border areas remained to be clarified (Wilkinson 1987, pp. 139-44, Jones and Ridout 2015, pp. 107-12).

${ }^{15}$ From about the thirteenth century (Prevost 2010, p. 35).

${ }^{16}$ The same is true for Tahert under Rustamid Ibādī control, it was known as a non-sectarian place where Sunnis as well as Christians had established themselves and took part in the trade (Rebstock 1983, pp. 27286, Savage 1997, p. 101).
} 
A major trading centre was Sadrāta in the eastern Algerian desert, which was in the eleventh century replaced by neighbouring Wargala (Warjlān, Ouargala) (Amara 2008, pp. 259-73, Aillet and Cressier 2018). Wargala also became an important centre, not just for trade but also for intellectual development in the later medieval period. As pressure from the north began to mount, many of the Ibādīis of Wargala began from the eleventh century to move further west to the oasis of Mzab (Mīzāb), where they built a series of villages or towns with Ghardaia as the largest (Cherifi 2015, pp. 130-48). As the Ibādī communities both in Wargala and other Saharan trade centres (such as Ghadames) died out, the Mzab became the dominant centre of Ibadism in the Maghreb, profiting from the continuous trans-Saharan trade going through the oasis. Today, about half of the Maghrebi Ibādīis come from Mzab, while Jerba and Jabal Nafusa share the other half.

This difference of movements north and south is of significance, because it put the retreating Ibādīs in two different political situations. In the Mzab, they remained isolated, but completely independent of external authority until the French arrived in the mid-nineteenth century. ${ }^{17}$ In Jerba and Jabal Nafūsa, on the other hand, they came under the authority of Sunni rulers of various brands, from different medieval dynasties to the Ottomans. ${ }^{18}$ These practiced various levels of accommodation or repression of the Ibāḍi minorities, but the best the Ibādị̂s there could hope for was internal autonomy under "foreign" rule. In the Mzab, on the other hand, they ruled themselves freely. But the Mzab community was always so small that there was no question of establishing an imamate of any sort there.

Instead, they divided their authority between a council of notables, a jamā' $a$, which took care of temporal matters, and a group of scholars, the 'azzāba, who ruled through a "circle", halqa (Faath 1985, pp. 60-93, Cherifi 2015, pp. 347-94). The structure of a halqa seems to have been codified first in Jerba in the early $11^{\text {th }}$ century as an organ for internal autonomy more than "political rule", but the structure appears to have been largely copied in independent Mzab. The council took over the formal legitimacy of the imàm, in a situation of kitmān (obscuring) where there is no evident imām to rule the community. The halqa should hold religious authority but was also involved for example (where relevant) in military defence (Prevost 2010, p. 35). It could consist of anywhere from ten to sixteen members, but was often composed of twelve scholars, thus it was often called the "council of twelve" (Mu'ammar 2007, pp. 70-4). Some religious positions seem to have been included ex officio, thus the prayer leader of the community would normally be a member, as well as the $q \bar{a} d \bar{i}$, the wakil al-awqā $f$ and the washer of the dead, otherwise prominent local scholars and notables. The council was led by a shaykh, whose authority however rested on the agreement of the council members.

The deliberations of the council were to be kept secret from the community at large. One important part of its duties was the application of walāya wa-barā'a. As mentioned, the Ibāḍ̄ hold (theologically) that grave sin puts you outside the Muslim community. That includes all non-Ibāḍi Muslims (categorized as munāfiqūn or kāfirūn al-nifāq, those who

\footnotetext{
${ }_{17}$ They paid a formal tribute to the Ottomans during their reign, but were otherwise left alone (Cherifi 2015, pp. 152-8).

${ }_{18}$ Prevost (2010, pp. 34-7) says the eleventh-century Zirid dynasty was particularly oppressive, while the Ottomans showed a tolerance of the Ibādī minority, which went through various recompositions over the centuries.
} 
deny God's bounty), but also Ibāḍīs who commit (grave) sin. Such sinners are excommunicated from the society, meaning that they had to leave the Mzab, on the decision of the halqa (Vigourous 1945, Holsinger 1980, Prevost 2010, pp. 95-6). They could only return by presenting repentance, tawba, to the community and have this accepted by the halqa. Thus, the council had the power to decide who was inside or outside the society of Muslims.

In the Mzab, each of the seven villages had their own halqa, and so had a certain degree of autonomy from each other. Indeed conflict, with violent clashes between these small villages (most of them within walking distance from each other) were frequent. To counteract this, there was an overall halqa of the Mzab villages, with representatives from each village council. Similarly, the Jabal Nafüsa community had a "grand shaykh of the mountain", an office that does not seem to have been used in the Mzab (Mu 'ammar 2007, p. 73).

\section{Ibāḍ̄i law}

There is no doubt that Ibādīis have their own madhhab, with a rich literature (much of which is being published in Oman). A systematic history of Ibādī law remains to be written, but some preliminary remarks can probably be made:

After Schacht denied the existence of any "ancient Ibādī law" among the original community in Bașra, some scholars have worked to prove the existence of such a law, to be found in the confirmed writings from Jābir b. Zayd and Rabī' $b$. Habīib as well as Qatāda b. Di'āma (d. 735) (al-Salimi 2017) and others. The Italian scholar Ersilia Francesca has in a number of articles demonstrated that in many instances, we can find a set of opinions ascribed to this early community in the eighth or ninth century that set them apart from the other Iraqi scholars, and indeed justifies the name of "ancient Ibādī law" (Francesca 2005, 2014). However, while we can discover these opinions using a form of "legal archaeology" on the early sources, later Ibādī jurists seem to have ignored or reversed their views, indicating a hiatus between the early law of the Bașra community and the later Ibāḍi jurisprudence that developed in Oman and the Maghreb. These later opinions do indeed often seem to have been fashioned on existing Sunni (and in a few instances, Shi'i) doctrines.

According to this opinion, which appears to be largely accepted, we probably have to distinguish between the actual opinions that may come from Jābir and his eighthcentury Ibāḍ̄i, or "palaeo-Ibāḍ̄i", contemporaries, and the opinions to be found in several major works ascribed to Jābir such as the hadith collection supposedly composed by his student Rabī' b. Habīb, and the collection of opinions known as Fiqh Jäbir b. Zayd. The hadìth work we ascribe to Rabī's, supposedly transmitted by Jābir, was in fact compiled by the Maghrebi scholar Abū Ya qūb Yūsuf al-Warjlānī (d. 1174) (Custers 2017, vol. ii, p. 487ff), and probably reflects a later, mature Ibāḍī law, as much as that of its purported transmitter (Wilkinson 1985). ${ }^{19}$

\footnotetext{
${ }^{19}$ Wilkinson is more forthright: The hadìth collection of Warjlānī "is frankly, a fake" (Wilkinson 2010, 435). Ibādì law had, he says, not been based on hadìth scholarship or needed it, but was a pragmatic collection of views developed over time in the community. Warjlānī's hadiths which suspiciously turned up in the Maghreb while being unknown in the east, only came into importance with the nahda from the seventeenth century onwards, see below.
} 
The mature Ibādī law began to grow in the ninth century, and saw a flowering in the eleventh to twelfth centuries. Two of the major works here come from each side of a bitter political and tribal conflict in ninth-century Oman between the two centres of Rustāq and Nizwā. In 886, imām al-Ṣalt b. Mālik from Rustāq had ruled for over thirty years (al-Rawas 2000, pp. 171-80, Wilkinson 2015, p. 51). However, the leading scholar of Nizwā, Mūsā b. Mūsā, claimed that imām al-Ṣalt was now old, decrepit and incompetent, and deposed him in favour a Nizwā relative. The Rustāqīs opposed this, as there had been no agreement among "those who bind and loose" on the issue, and the imām was anyway in fact competent. By deposing a valid imām, Mūsā had committed a grave sin and must himself be excommunicated. Thus, a civil war between the two parties ensued. This was the conflict that caused the fall of the first Omani imamate in 893, when one side called in the enemy Abbasids to help them.

In later law, there was agreement that the deposition of al-Salt was invalid. But the Rustāq current insisted that $\operatorname{bara}^{\prime} a$ must be applied not just to the Nizwā scholars who had deposed the legitimate imām, but also to everyone who did not support the excommunication of these scholars. The Nizwā viewpoint was that, while imām al-Ṣalt should not have been deposed, prolonging this conflict and the claim of tabri ${ }^{-} a$ (declaring $\left.\operatorname{bar}_{\bar{a}}{ }^{\prime} a\right)$ past the fall of the imamate was divisive and extremist.

The two dominant legal scholars of this early period came from different sides of the conflict. Perhaps the most influential early scholar was Abū Sa'îd Muhammad alKudami (late $10^{\text {th }}$-early $11^{\text {th }}$ century, wrote $K$. al-Istiqāma), who favoured the more moderate Nizwā school (Francesca 2014, p. 123, Ziaka 2015, pp. 93-100, Custers 2017, vol. 1, pp. 343-4). But almost equally important, and cited as a foundational text of Ibāḍ̄ fiqh, was his Rustāqī opponent, 'Abd Allāh b. Muḥammad Ibn Baraka (early 11 ${ }^{\text {th }}$ century). His K. al-Jāmi' became a standard work commented on and developed by his students and later Ibāḍ̄ scholars (Custers 2017, vol. 1, p. 199ff). While the Nizwā moderation may be said to have prevailed, allowing for the later unification of Oman under one imām, both authors and their works remained at the core of Ibādî figh for the centuries that followed.

From the early period, we see a connection between the east and the west in Ibādị legal thought. An early example of this is Abū Ghānim al-Khurāsānī, who went from the east to the Rustamid state in the early ninth century, we know his basic work on Ibādì figh, the Mudawwana al-kubrā, from a copy made in Jabal Nafūsa (Custers 2017, vol. 1, p. 207; EI(2), I, 120). Important medieval scholars in the west included, in addition al-Warjlāni already mentioned, Yahyyā b. Abī Khayr al-Jannāwnī (fl. c. 1150) (Custers 2017, vol. 2, pp. $243-4) \cdot{ }^{20}$

At this time, in the eleventh and twelfth century, the original open-ended discussions of Islam's "formative period", was maturing into the more established currents we know as Sunnism and Shi'ism in its various forms, in south Arabia in the shape of Shāfi ${ }^{\prime} \overline{1}$ Sunnism. Ibādī legal debate also had to relate to this, partly by accepting elements of Shāfi ${ }^{\prime}$ law as acceptable within their system, while at the same time affirming some aspects as specifically Ibādīi, to establish their separate identity, a process that Wilkinson

${ }^{20}$ For further scholars of this period, west and east, cf. the detailed three-volume bibliography of Custers (2017). The mentioned figh works are among the many edited and published in Oman from the 1970s onwards). 
calls "madhhabization" (Wilkinson 2010, pp. 413-37). The basis for this appears however to be mostly pragmatic.

\subsection{The Ibā}

In the nineteenth century, an intellectual resurgence seems to have taken place in Ibāḍ̄ thought, most often called "the Ibāḍī nahda". Opinions vary on exactly how far back we should trace this, but an important early figure appears to have been 'Abd al'Azīz al-Thamīnī (1718-1808). He wrote, among many other works, a compendium of Ibāḍ̄i law, Kitāb al-Nìl wa-shifa' al- 'alīl, which was to become a standard work of Ibāḍī fiqh.

This is mostly printed together with a much larger commentary written by a student of his students, Muhammad b. Yūsuf Ațiyyash ${ }^{21}$ (1820-1914), the Sharh al-Nìl, a work that was widely spread throughout the Ibādī world (Francesca 2018a). ${ }^{22}$ The noticeable thing here is that these two prominent scholars did not hail from Oman, but from the small minority in Mzab. In fact, they came not even from Mzab's largest town-village, Ghardaia, but from the smaller village of Benī Yisguen, which then became a centre for Ibāḍ̄ thought. Ațfiyyash himself remained in the Mzab all his life, except for brief visits outside, including two pilgrimages to Mecca.

In spite of this, he was quickly recognized for his great knowledge and work for revival of Ibāḍi thought, following on from al-Thamīnī as well as from his older brother Ibrāhīm, who had lived for a number of years in the Hijaz.

Attiyyash had conflicts with more conservative Mzabīs, but his renown - he was commonly called the quțb al-a'imma - was also recognized locally, particularly in his home town Benī Yisguen. He was elected to the 'azzāba council there and served on it for much of his life. In addition to his considerable production of writings in various scholarly fields, he also established a school in his town, where he taught the reformed vision of Ibāḍ̄ thought (Ourghi 2006, pp. 281-90).

His lifetime was marked by the major transformation in Mzabi history. During alThaminin's time, at the outset of the nahda, Mzab was still protected from the Sunni rulers of the north as it had been for centuries, and remained so during the first two decades of French presence in Algeria. It took the colonial forces time to begin exploring and expanding their influence into the desert, and the noticeable mahdist revolt in Wargala in 1851-54 kept them occupied (Clancy-Smith 1994, pp. 168-213, Vikør 1995, pp. 212-13). That revolt did however bring the need to control the desert to their attention, and in 1853 they entered the Mzab and Ghardaia for the first time (Ourghi 2006, pp. 99-100,

\footnotetext{
${ }^{21}$ There is absolutely no coherence whatsoever on how to spell his last, Berber, name. Variants, all apparently familiar to the Mzab and Berber pronunciation, vary from Tfyeche, to Ațīsh (Brockelmann 1943, S II, p. 892); Ittfayyish (Custers 2017, vol. 2, p. 180), Ațfayyish or Ațtafayash. The final long ā in Encyclopaedia of Islam's Ațfiyāsh is however wrong (EI(2), i, 736, J. Schacht). Ourghi (Ațfaiyash) says it is composed of the Berber words attaf, aiya $\bar{a}$, and ash, meaning "take, food, eat", indicating hospitality (Ourghi 2006, p. 108). That does not really bring us much further, so we settle here somewhat haphazardly on Ațiyyash.

22 Seven volumes of the Sharh were published in Cairo in Atfiyyash's lifetime 1888-89, the last three posthumously by his grand-nephew Ibrāhīm in 1924-5, by different publishers, partly al-Bārūnīya (related to the Libyan Ibāọ̄i Bārūn̄i family), partly by Mṭ. al-Salafìya. Funding came from largely from sultan Barghash in Zanzibar. (On the relation between Zanzibar and Ațfiyyash, see Ghazal 2010).
} 
Cherifi 2015, pp. 163-73). At this point they lacked the power or inclination for permanent occupation, so they instead made a protectorate agreement. In return for withdrawing their support for the Wargala revolt, the Ibādīs were allowed to manage their internal affairs in the traditional manner under the 'azzāba council.

Thirty years later, the French had greater appetite, and in November 1882 occupied and annexed the Mzab without any resistance. Thus, from this point on, the Mzab was, like their northern co-religionists in Tunisia and Tripolitania integrated into a Sunnidominated (but French-ruled) larger state.

Many of the Ibādī notables welcomed the agreements with the French. Ațiiyyash was not one of them (Ourghi 2006, pp. 343-56). He argued against the French influence, and was considered a voice of resistance, albeit verbally only. He urged for a jihāa against colonialism in general but saw the return to a true Islam and unity among Muslims as a necessary basis for this resistance (Ourghi 2006, p. 355ff). ${ }^{23}$ Then, boycotts and rejection of cooperation were the weapons to be used. That this latter emphasis is inspired by the Ibādị concept of barā' $a$ is evident.

Atfiyyash appears to have presented two aspects of this in his doctrine. On the one hand, he argued for a strict application of walàya wa-bara $\bar{a}^{\prime} a$, and thus emphasized the need to preserve the Ibādī community as separate. His reform thus suggests puritanism, purism and conservatism. At the same time, he appears also to be open to intellectual contact with Sunnis and Mālikīs, he read their works, consulted with them, and indeed considered the Sunni scholar al-Suyūțī as the model for his comprehensive reform. Here he presented a radical opposition to the earlier generations of Mzabi scholars, who seem to have shied away from this form of scholarly contact, and he was opposed by the traditional scholars for his new views. His view may perhaps be summed up that as long as the Ibāḍi separateness and community was preserved, it would be less dangerous to communicate with outsiders. Secure in yourself, you need not fear contamination.

Atfiyyash thus worked for the promotion of identity and community on a number of levels: On the very lowest level, for his community of reformist scholars in Benī Yisguen against more conservative Ibāḍ̄s in Ghardaia. Then for the "true Muslims" of Ibāḍ̄ theology against the encroaching Sunnis coming in from surrounding Algeria. As a Berber, he worked for the promotion of Berber identity, although his scholarly language was of course Arabic, and he sought to promote both Berber usage and expand the competence in Arabic (and thus scholarly knowledge) among the students that came to his school. And finally, for all Muslims (in the more expansive, "those who pray" sense) against the colonial power.

\subsubsection{The Ibādī nahda in Oman}

While the central role of the Mzabis in this upsurge of Ibādī legal production was generally recognized, it also sparked a response in Oman. The main scholar who is considered the counterpart to Ațiiyyash's reform scholarship there was Nūr al-Dīn 'Abd Allāh b. Ḥumayyid al-Sālimī (1869-1914) (EI(2), viii, p. 993 [J.C. Wilkinson], Custers 2017, vol. 1, p. 509ff, Francesca 2018b). Blind at a young age, he is best remembered as an

${ }^{23}$ Exactly how much of Ațfiyyash's attitude was based on anti-colonialism and how much on inherent conservatism is disputed among historians, cf. Cherifi 2015, pp. 379-81. 
historian, but also wrote a number of figh works. Inspired by the Mzabi movement as well as previous reformist tendencies in Oman, he worked to restore vitality to Ibādī law as well as indicate openness to others (Leonard 2015). However, he is perhaps equally well known for his political activity: It was he who started the revolt for imām Sālim ibn Rāshid in 1913. He was however accidentally killed in 1914, and thus did not see the imamate restored under the Sīb agreement.

While the imamate and sultanate had separate administrations, and thus separate legal structures, it is interesting to see that the end of the imamate did not necessarily mean the end of Ibādī legal authority. This can be seen in the biographies of some leading Ibāḍ̄ legal scholars of the twentieth century: Sālim b. Hammūd al-Siyābī (1908-93) was a companion of imām al-Khalīlì and qā was appointed to the mahkama of Masqat (Custers 2017, vol. 1, p. 554). Muhammad b. Shāmis al-Bațtāshī (b. c. 1910s) was appointed qā ḍ̄ of Bidbid by imām al-Khalìlī, and he remained in Nizwā after the fall of the imamate (al-Bațtāshī 1984, vol. 1, I-IV, Custers 2017, vol. 1, p. 123). However, sultan Qābūs brought him as well to the court in Masqat. Thus, imamate legal thinking seems to have continued under the sultanate and in its legal structures, in spite of the insistence that Oman has a "non-madhhabi" all-Islamic law.

6.1.2. The Maghrebi nahda in the twentieth century

In Algeria, Attiyyash was followed by a number of prominent scholars who were considered part of the nahḍa. One was his grandnephew Abū Ishāa Ibrāhīm Attiyyash (1886-1965), who besides extensive works for publications, was politically active and banned from Algeria, settling in Egypt from 1923. He also worked to promote the cause of the deposed Omani imām Ghālib b. 'Alī at the UN (Shinar 1961, pp. 113-19, al-Kāmilī 1966, Jomier 2012, Custers 2017, vol. 2, p. 173).

Another prominent scholar was Abū 'l-Yaqụān Ibrāhīm b. 'Īsā (1888-1973) (Nāṣir 1980, Bū Hajām 1985), who had been a student of the elder Ațfiyyash, later went to Tunisia to study at Zaytūna alongside Abū Ishạa q and made contacts with the Destour nationalist movement there. On his return to Mzab, he founded several newspapers and is also known as a prominent poet (Custers 2017, vol. 2, p. 25).

The main figure of the twentieth century nahḍa is however Ibrāhīm b. 'Umar Bayyū (1899-1981), who was a student of Abū Yaqzān (Jomier 2012, Hoffman and al-Shueili 2012, Cherifi 2015, pp. 378-94). ${ }^{24}$ But it was clear that with the turn of the century, and new currents of thought, a change had occurred in the direction of the movement.

Bayyū was born in the village of Guerera on the outskirts of the Mzab oasis and began his studies there. He was only fifteen when Attiyyash died and had not studied with him, ${ }^{25}$ but the reformist ideas the quțb had planted was clearly part of his intellectual background. He also went to Tunisia to study at the Zaytūna university and came into contact with the Destour movement. He began reading the Manār, the journal published by Rashīd Rị̣ā and was influenced by him and Muhammad 'Abduh, returning to Mzab

\footnotetext{
${ }^{24}$ There is a vast, mostly laudatory, literature on Bayyūụ produced in the M'zab; e.g. A 'washt 1987, Bū Hajām 1991, Nāṣir 2002; cf. also Bayyūụ 1990.

${ }^{25}$ A 'washt (1987 p. 35) says he briefly met the quṭb when Bayyū ḍ was eight.
} 
with the intention of furthering the reform movement. In particular, he pressed for educational reform, combining modern subjects with a new reading of the Islamic sources, as 'Abduh had done in Egypt and similar to the Ben Bādīs movement in Algeria, ${ }^{26}$ which he joined. Like Atfiyyash, he gave particular importance to the teaching and use of Arabic and emphasized the instruction of Arabic parallel to French in the schools he developed.

Bayyū the reform and re-invigoration of this body became one of his primary goals. He wanted to open the Ibādịs to the wider community and favoured the extension of Ibādị traders into Algerian society at large. A particular point in question was that Ibādī women, traditionally secluded from contact with outsiders through strict tabri ' $a$, must be able to leave the Mzab into Algeria like the male Ibādịs.

Clearly, this more liberal interpretation represented a needed redirection of Ibādī doctrine in the twentieth century. It therefore gained support, and was accepted as standard doctrine throughout the Mzab, as well as among Ibādīis outside in Algeria from the 1930s onwards (Prevost 2010, p. 37). Only in Attiyyash's native town of Benī Yisguen were Bayyū d's doctrines rejected, and the traditional secluded interpretation of walāya wa-barā'a upheld.

In the 1940s, Bayyūd also changed his political stance (Jomier 2012, 2015). Until then, he had sympathized with the ideal held by the Mzab 'ulama' to isolate themselves from the colonial power. The prevailing sentiment was that the best solution to aim for was the protectorate agreement that had been in force between 1853 and 1882. In 1947, however, Bayyū structures in French Algeria and take part in the elections the French organized. In spite of initial opposition, including from his close allies, his views came to prevail, and Bayyū di himself became the main spokesman of the Mzab to the authorities in the remaining years of French presence there, eventually rallying the Ibādī community (with the exception Benī Yisguen) around him.

While Bayyūd was thus close to a more conservative branch of the nationalist movement, his religious policies were clearly at odds with the socialist oriented brand of nationalism espoused by the new authorities of independent Algeria. They saw him primarily as a religious obscurantist, and he remained estranged from national political power during the last two decades of his life.

\subsection{A reformist view on marriage? Bayyū}

This raises the question of the nature and limits of Ibādī reformism in social and legal affairs. ${ }^{27}$ One source for this is Ibrāhīm Bayyū d's fatwās. In the mid-twentieth century, he had clearly gained an authority in his community that led him to be sought out for a varied set of questions for social relations generally, and for how to adapt to modern life in a French-dominated Algeria. Queries came even from Jerba in Tunisia, as well as from his native Mzab. A selection of these were edited and published after his death in two

\footnotetext{
26 “L'Association des oulémas musulmans algériens”, which Bayyūọ joined.

${ }^{27}$ Jomier, for example, in his recent thesis argues that reformists' opinions in family law were hardly reformist in content (Jomier 2015, 423-36).
} 
volumes as Fatāwō Ibrāhīm Bayyūụ (Bayyūḍ 1988). As we do not have access to the original fatwās, nor their dates, the best approach is to see this collection as a collective view of the author and his fellow scholars ${ }^{28}$ in his mature period of the 1950s to 1970s.

The section on zawāj, marriage, contains about 80 fatwōs. They vary in length from a few lines to some two or three pages. Many of them repeat the same question with identical answer, or with details that supplement the first query, which gives an impression that, while edited, the queries represent actual questions posed by members of the community. They can be grouped into these main themes:

- On dower (sadaqa). Is there a limit to how much can be agreed that a husband should pay his bride? No, there is no fixed limit, but it is disapproved (makrūh) to ask for more than what is common in the village.

- On impediments to marriage. There are many questions about the issue of "milk siblings", the principle that sharing a wet-nurse creates fictional family relationship that prevents marriage. But how long does the suckling period that creates such an impediment last? The answer is invariably twenty-four months after birth, such is the view "among most Ibādīis". The impression is that this is discussed because there are different opinions among Sunni madhhabs on this issue, thus it is scholarly interesting.

- A similar motivation seems to fuel the many queries about whether a man can marry a woman he has been found to have had premarital sex with ( $z \bar{a} n \bar{\imath}$ bi-zānīya). Bayyū de here imposes the Ibādī view that this is absolutely forbidden, quoting Jābir that they should preferably avoid even looking at each other. This is a point where Ibādī law differs markedly from Sunni views, where such a regularization of a pre-marital relationship is generally approved of. Bayyū does however recognize that this is an issue where there are different opinions, based on ijtihād (legal interpretation).

- More liberal are perhaps his answers to those who are worried that a statement of divorce (talāq) made in anger or just stated "in the heart" or as part of a threat: "If I do not complete this labour, my wife shall be divorced from me" is valid and prevents remarriage. Here Bayyū emphasizes niya, intention: If you did not actually mean to divorce her, then the expression itself does not make it so. This is, however, also a standard view also among Mālikīs, the madhhab dominant in the Maghreb (as opposed to the literalist Hanafī view).

- His discussion about what kind of sexual acts performed in marriage are illegal and thus forces a divorce and ban on remarriage, is quite forthright and direct. Here he several times denounces the pernicious influence of French and other foreign obnoxious customs, immoral and disgraceful films and magazines. But in law, he insists that while most of these are makrūh, vile, they are not illegal in the sense of breaking up a marriage.

- The large section on birth control and contraception also appear to aim to reassure those who ask. His view is quite uniform: Birth control and contraception is perfectly all right and legal, in whatever form it takes, be it

\footnotetext{
${ }^{28}$ The editor was Bakīr Muhammad al-Shaykh Bilḥājj, a scholar from Bayyūụ̂s native Guerara.
} 
by pills and medicine or other methods, as long as both spouses agree. Many bolster their request by claiming medical or other reasons, but his answer is that this is immaterial, it is always allowed - except for in one case: If it is for fear of not being able to provide for more children, then you do not have faith in God's ability to provide. On abortion, however, Bayyūẹ is quite strict, but in accordance with Mālikī figh: It is forbidden from the point of contraception. The issue of how many weeks have passed into pregnancy, discussed by other madhhabs, is only pertinent to what kind of penance should be paid.

Abortion is, like many of the other issues, evidently also relevant for Algerian family law, but the fatwās ignore this state aspect completely. The only reference to the larger Algerian context is that the first, and detailed, fatwa in favour of birth control is in response to the national High Islamic Council of Algeria, clearly seeking Bayyūẹ's support for a national policy on the issue. Otherwise, while legal in form and relating to figh and the Sharì' a, the fatwās mostly appear as moral recommendations and on issues of personal piety. Thus, in the cases where an act requires a penalty to be paid, that is always to be made to the community, but most often through a tawba, admitting the sin publicly and seeking the forgiveness of the community. That this is pious rather than practical, is demonstrated in the penance to be paid for an abortion, which he several times states is a ghurra. This term (from a hadìth by al-Bukhārī) is clearly quite unknown to the asker, so he in one instance deigns to explain that it means freeing a female slave. As such no longer exist, it must be replaced by the relevant sum of money, according to classical figh.

Further research is needed to contextualize these opinions in the intersection between classical Ibāḍ̂ figh, the opinions of the majority Mālikī (in the Maghreb) and Shāfi 'ì (in Oman) law, and social developments. It is noteworthy that there are so few references to the Mzabis' status as Algerian citizens and subject to Algerian law, even on issues (like abortion) where there clearly existed a state law that had competence. But even more striking in topics of morality and social practice - such as whom you can marry is that the existence of ahl al-qibla, Sunni Muslims, is not discussed at all. Marrying "outsiders" is only discussed in relation to the ahl al-kitäb (that is, French) partners - even though the period Bayyūd lived through saw a rapid increase of Sunni settlers in the Mzab. ${ }^{29}$ Thus, the issue of marriage across sects must have been relevant.

The fatwās thus seem to refer to an ideal situation where the Ibāḍi community was master of its own destiny. In the real-world context where they were subject to state law in addition to their own rules, the focus is thus on the kind of social and pious sanctions that could be applied beyond any state restrictions, like tawba and payment of fixed penalties to the village community - but without giving any formal indication that this is anything but pure law. As for the legal discussion in the opinions, it is clear that Bayyū dọ does wish to emphasize Ibāḍ̄ particularism when Ibāḍ̄ opinions clearly differ from Mālikī ones, as the marriage of zānī bi-zāninya, to draw a line in the sand, but at the same time accommodate to social demands when that can be done without opposing

\footnotetext{
${ }^{29}$ In his discussion, however, he puts unexpected emphasis on that while Muslims may marry Christians and Jews, marriage to those who "reject religion", that is heathens, is not allowed. Polytheists were not an issue in the Sahara, but it seems more likely that he is referring to French or other atheists than to Sunni Muslims with "those who reject religion".
} 
Ibādī doctrine, as with the quite open acceptance of birth control. Thus, we are seeing a reformism that tries to balance the ideal of Ibādī particularity with the social reality of situation in mid-twentieth century Algerian Sahara.

\subsection{Ibāḍ̂̀ law and Ibāḍ̄ politics}

From the brief survey of Ibāḍi law and Ibāḍi history and politics, we can see that it is almost impossible to separate the two. Ibādism may not have been so direct an outcome of Șiffīn as Ibādī self-history proclaims, but the later internal conflicts over the deposition of imām al-Ṣalt in 886 loomed heavily over the legal development in the early period and led to the establishment of a "Nizwā current" and a "Rustāq current". Even clearer is the combination of politics and law in the history of the reform movement in the nineteenth and twentieth centuries, with the Mzabi Atfiyyash as well as his successors in various ways all being caught up in the struggle that was, for the former abut Mzabi, Berber and Ibādī identity, among the younger scholars also clearly nationalist. That the main Omani proponent of legal development, al-Sālimī was also the driving force between the revolt against the sultanate that led to the establishment of the peculiar division of Oman into a sultanate and an imamate, the one more closed to the outside (Muslim and non-Muslim) world than the other, cannot be a coincidence. But how exactly should we understand this connection?

It is premature to give a well considered answer to this, because so many of these events are understudied, and some still controversial. Oman is balancing its Ibāḍī identity with the need to encompass all Muslims into its state; the Omani Islamic legal system is both an Ibāḍ̄ legal system and a "non-madhhab, all-Islamic" one. ${ }^{30}$ In Algeria, the Ibādīis are now under pressure from increasing Sunni immigration into the Mzab, and the oasis has seen continuous clashes between Berber Ibādīs and Arab Sunnis over the last few decades. The rise of Sunni Salafism and radical Islamism has not lessened the tension in the region (BBC News 2015).

Nevertheless, we may reflect a little on the topics brought up. Many of the most important issues where law, theology and politics intersect relate to the issue of walaya $w a-b a r a \bar{a} ' a$, meaning where to draw the boundaries of the Muslim society. As mentioned, the topic is strictly speaking discussed under $u s ̦ \bar{u} l$ al-dīn and not under figh, as the Ibādīs accept that the Sharī'a encompasses both Ibāḍ̄is and non-Ibādịis. Ibāḍi fiqh works do not necessarily discuss whom they address, but many do include sections on din, where the issue appears, and may otherwise refer to "opponents", by which is meant non-Ibāḍ̄ Muslims, assuming evidently that the ahkām they discuss are for the true Ibāḍi Muslims. At the same time, Ibādịs, particularly in the Maghreb have always relied on trade, mostly long-distance trade for their survival. It would be impossible to carry out such trade if the trading partners were to be considered as untouchable "heathens". Thus, Ibādī acceptance of real-life interaction is inevitable, and has always been there.

The question is where to draw the line. If we look at some of the contexts that Ibādīs have worked under, we find in the early Rustamid period a trading state with a ruling dynasty that combined a distant, Persian, past with increasing intermarriage with local Berber

\footnotetext{
${ }^{30}$ See Siegfried 2000: Omani citizens can in many cases choose whether to apply a more lenient "all-Islamic" legal rule or a more restrictive Ibādịi one.
} 
tribes, and which appear to have been open and non-sectarian to foreign traders - as far as our sources tell us, which is not very far. In Oman, Ibādism quickly integrated into tribal culture, so that Ibādīi identity became intermixed with Omani tribal one, and has remained so until the present century. When the imamate was re-established in the seventeenth century, it was on a dynastic, tribal basis, and morphed with little resistance into a non-imāmī sultanic one. As this sultanate came to rule non-Ibāḍīs as well as Ibādīis, not just in Oman but even more so in East Africa, where Ibādīis were always a minority, it had to combine Ibādī-ness with a non-sectarian approach. Thus, court records in Zanzibar show Ibāḍ̄ and Shāfi 'ì judges working together in a shared court. ${ }^{31}$

The Omanī nahda was clearly linked to the pro-imāmī revolt against this sultanic rule. The rebels are often portrayed as reactionaries who wanted to close their eyes to the very limited modernity that the pro-British sultans represented. But in his legal work, the rebellious al-Sālimī also seems to open Ibādī thinking to reform and adaptation to the modern world. Nevertheless, a regeneration of Ibāḍ̄ identity in a region which (for political and military reason rather than intent) came to be more exclusively Ibādī than that of the sultanate, could be linked to the concept of withdrawal, barā 'a from non-lbādī Muslims.

The important political factor is however that in Oman, be it sultanate or imamate, the Ibādīis had political power and more or less numerical superiority. That was never on the cards in the Maghreb after the medieval period. Here, they had to adapt to a "subaltern" situation where they could either be isolated - but never so isolated as to abstain from trading relations - or subject to non-Ibādī rule. The major change for the Mzab came in 1882 with the French occupation that opened up the oasis to the Sunnis, and it is therefore of particular importance to look at the response of Muhammad Attfiyyash, who lived through this period, and in his legal thought clearly reacted to it. What did barā' $a$ mean before and after 1882 ?

During Atfiyyash's lifetime, the first thirty years of occupation, there seems to be a combination of opening the doors to Sunnism intellectually, interacting with Sunni legal thought, at the same time as preserving the Ibādī community socially, raising stricter limits for interaction. While Ibāḍ̄ traders increasingly went out into Sunni Algeria and established trading diasporas in the north, strict rules were established for those who went there. Only men were allowed, no Ibādī women could leave the Mzab (Vigourous 1945). ${ }^{32}$ But the Ibāḍ̄ "expat" traders were required to marry Ibāḍ̄ women, and to return regularly to the Mzab to maintain close contacts with the home community. Social relations with Sunnis beyond what was required for trading was discouraged. Nevertheless, they were allowed to marry Sunni women as well, and could even bring them to Mzab on their return - much in the same way as any Muslim can marry an ahl al-kitāb woman.

The issue of marriage is probably a good marker for $\operatorname{bar} \bar{a}$ ' $a$, and attitudes to marriage across the "Muslim" (Ibāḍ̄i) - "ahl al-qibla" divide varied among jurists (Kondo 2015). However, in social reality, the issue of Ibāḍ̄ / non-Ibāḍi marriage often disappears into a general principle of $k a f a{ }^{\prime} a$, compatibility between marriage partners (al-Azri 2013). If

${ }^{31}$ Bang and Vikør 1999. These cases refer to the situation under British rule, however, it remains to be seen if the relations were as close when the Omanis ruled alone.

32 See a 1928 confirmation of this ban in Prevost 2010, pp. 95-6. 
you are, on the basis of social equality, assumed not to marry outside your tribal equivalence, and these tribal or family relations are Ibādīs anyway, it is hard to say if social $k a f \bar{a} ' \bar{a}$ covers up a religious exclusivity or not. As we have seen, the reformist scholars of twentieth-century Mzab appear to evade the issue completely, possibly due to internal tensions between integrationist and isolationist tendencies among the population.

The application of law is generally considered to be linked to the political authority of a state, which applies the law. Much figh of course deals with rituals, 'ibādāt that rely on personal morality and not state authority, and many Ibāḍi fiqh works are also focused on rules of 'ibādāt where Ibādī rules may not differ substantially from Sunni or Shi'i ones. In those fields, it is not so surprising that the Maghrebi and the Omani legal traditions flow into each other, which they do: Omanis (and Zanzibaris) study and refer to the Maghrebis as the authority ("the quțb [Muhammad Ațiyyash] says" closes the discussion). ${ }^{33}$ The surprising element would perhaps rather be the relative importance of the Maghrebi input, given their small size compared to the Oman, and of course that they do not have any state authority in their back. Perhaps this could be explained by the fractious situation of the tribally-based Omani state, but the Mzab was no less fractious, on a smaller scale. But scholarship may have been more central to that community without a state authority, although this is at the present stage conjectural. Clearly, research into the legal literature will cast more light on the preoccupations of these scholars, and how the absence of either sultan or imām in the Mzab, the minority situation of the Jerba and Tripolitania Ibādīs under Sunni rule for centuries, and the situation of ruling over non-Ibādịs in the Oman and East Africa influenced the mu 'àmalāt works of the various centuries. This is thus a field that is only about to open up.

\section{References}

Aillet, C., and Cressier, P., eds., 2018. Sedrata: Histoire et archéologie d'un carrefour du Sahara médiéval. Paris: Casa De Velázquez.

Amara, A., 2008. La structuration des ibadites-wahbites au Maghreb (XIe-XVe siècle). Annales Islamologiques, 42, 259-73.

al-Azri, K.M., 2013. Social and Gender Inequality in Oman. London: Routledge

A 'washt, B.b.S., 1987. al-Imām Ibrāhīm Bayyūḍ: wa-jihāduhu al-islāmī fì 'l-Jazā'irr. Ghardaia: al-Mațba'a al-'arabìya.

Bang, A.K., and Vikør, K.S., 1999. A Tale of Three shambas: Shāfi 'ì-Ibāḍī legal cooperation in the Zanzibar Protectorate. Sudanic Africa: A Journal of Historical Studies, 10, 1-26 \& 11, 2000, 1-24.

al-Baț̣āàsī, M.b.S., 1984. K. Ghāyat al-ma'mūl fì 'ilm al-furū 'wa'l-ușūll. Masqaṭ: Salțanat 'Umān: Wizārat al-turāth 1404/1984.

Bayyūụ, I.b. 'U., and al-'Umanī, I.b.S., 1971. Ajwibat wa-fatāwā. Nālūt: Dār al-da'wa $1390 / 1971$.

\footnotetext{
${ }^{33}$ For an example in the aforementioned Omani scholar al-Batțāshī (1984, IX, 5, and passim).
} 
Bayyūḍ, I.b. 'U., 1988. Fatāwā al-imām Ibrāhīm Bayyūḍ (2 vols.). Ghardāya: al-Maṭba'a al'arabìya.

Bayyūụ, I.b. 'U., 1990. A 'mālì fì 'l-thawra, Cairo/Ghardaia: Jamī'at al-turāth n.d. [1990].

BBC News, 2015. Ghardaia clashes: At least 22 dead in Algerian oasis city. BBC News [online], 8 July. Available from: https://www.bbc.com/news/world-africa33455563 [Accessed 12 May 2020].

Brockelmann, C., 1943. Geschichte der arabischen Litteratur. Leiden: Brill.

Broucek, J., 2018. Generic Islam? Official Religious Discourse in the Sultanate of Oman. In: A. Salimi, ed., Oman, Ibadism and Modernity. Hildesheim: Olms, 325-36.

Bū Ḥajām, M.N., ed., 1985. Abū 'l-Yaqzēan fì 'l-dawrīyāt al- 'arabīya. Ghardaia: al-Mațba 'a al-'arabīya.

Bū Ḥajām, M.N., 1991. al-Shaykh Bayyūẹ wa'l- 'amal al-siyāsī. Ghardaia: al-Maṭba 'a al'arabìya 1412/1991.

Cherifi, B., 2015. Le M'zab: Étude d'anthropologie historique et culturelle. Paris: Ibadica.

Clancy-Smith, J.A., 1994. Rebel and Saint: Muslim Notables, Populist Protest, Colonial Encounters (Algeria and Tunisia 1800-1904). Berkeley: University of California Press.

Crone, P., 1994. Even an Ethiopian slave: the transformation of a Sunnī tradition. Bulletin of the School of Oriental and African Studies [online], 57, 59-67. Available from: https://doi.org/10.1017/S0041977X00028111 [Accessed 12 May 2020].

Cuperly, P., 1991. Introduction à l'étude de l'ibādisme et de sa théologie. Alger: Office des publications universitaires.

Custers, M., 2017. Al-Ibādilyya: A Bibliography. Hildesheim: Olms.

Dbeez, N., 2017. Les ibadites du djebel Nafûsa après la révolution libyenne. In: V. Prevost, ed., Les Ibadites. Mode de vie, organisation et patrimoine d'une minorité musulmane. Toulouse: Presse Universitaires de Midi, 60-8.

EI(2): H.A.R. Gibb et al., eds., 1960. Encyclopaedia of Islam (New Edition) (12 vols. and Supplement). Leiden: Brill, 1960-2002.

Ennami, A.K., 1971. Studies in Ibadism. Ph.D. thesis. University of Cambridge.

Faath, S., 1985. Die Banû Mîzâb: Eine religiöse Minderheit in Algerien zwischen Islation und Integration. Schessel: Hanspeter Mattes.

Francesca, E., 2005. Early Ibāḍ̂̄ Jurisprudence: Sources and Case Law. Jerusalem Studies in Arabic and Islam, 30, 231-63.

Francesca, E., 2014. Constructing an Identity. The Development of Ibādi Law. In: A. Ziaka, ed., On Ibadism. Hildesheim: Olms, 109-33.

Francesca, E., 2018a. Ijtihād and the Ibāḍ̄i Reform Movement in North Africa: Shaykh Muḥammad Ațfayyish's 'Re'-Interpretation of Kitāb al-Nīl. In: A. al Salimi and R. Eisner, eds., Oman, Ibadism and Modernity. Hildesheim: Olms, 69-80. 
Francesca, E., 2018b. Religion and Politics in Contemporary Omani Ibāḍism. In: A. al Salimi and R. Eisner, eds., Oman, Ibadism and Modernity. Hildesheim: Olms, 87-95.

Gaiser, A.R., 2010. Muslims, Scholars, Soldiers: The Origins and Elaboration of the Ibād $\bar{\imath}$ Imāmate Traditions. New York: Oxford University Press.

Ghazal, A.N., 2010. Islamic Reform and Arab Nationalism: Expanding the Crescent from the Mediterranean to the Indian Ocean (1880s-1930s). London: Routledge.

Ghubash, H., 1998. Oman. Une démocratie islamique millénaire: La tradition de l'imâma. L'histoire politique moderne (1500-1970). Paris: Maisonneuve et Larose.

Hoffman, V.J., 2012. The Essentials of Ibāḍ̄ Islam. Syracuse University Press.

Hoffman, V.J., 2015. Historical Memories and Imagined Communities. Modern Ibadi Writings on Khārijism. In: A. Ziaka, ed., On Ibadism. Hildesheim: Olms, 137-50.

Hoffman, V.J., and al-Shueili, S.b.A.b.A., 2012. Ibâḍ̂ Reformism in Twentieth-Century Algeria: The Tafsîr of Shaykh Ibrâhîm Bayyûḍ. Revue des Mondes Musulmans et de la Méditerranée, 132, 155-173.

Holsinger, D.C., 1980. Migration, Commerce and Community: The Mīzābīs in Eighteenth- and Nineteenth-Century Algeria. Journal of African History [online], 21(1), 61-74. Available from: https://doi.org/10.1017/S0021853700017862 [Accessed 12 May 2020].

Jomier, A., 2012. Iṣlâh ibâdite et intégration nationale: vers une communauté mozabite? (1925-1964). Revue des mondes musulmans et de la Méditerranée [online], 132, 175-95. Available from: https://doi.org/10.4000/remmm.7872 [Accessed 12 May 2020].

Jomier, A., 2015. Un réformisme islamique dans l'Algérie coloniale: Oulémas ibadites et société du Mzab (c. 1880-c.1970). Ph.D. thesis. Le Mans: SCE (Angers)/Centre de recherches historiques de l'Ouest (Rennes).

Jones, J., and Ridout, N., 2015. A History of Modern Oman. Cambridge University Press.

al-Kāmilī, A.R.'A.A.b.M., 1966. Abū Isḥāq Ibrāhīm Atfiyyash. Constantine: Maṭba at alShihāb, 1385-6/1966.

Kenney, J.T., 2006. Muslim Rebels: Kharijites and the Politics of Extremism in Egypt. New York: Oxford University Press.

Kondo, Y., 2015. The Development of Ibādi Jurisprudence in Oman in the 3rd/9th and 4th/10th Centuries: A Preliminary Study of Some Marriage Issues. In: B.

Michalak-Pikulska and R. Eisner, eds., Ibadi Jurisprudence. Hildesheim: Olms, 8191.

Leonard, D., 2015. A Basis for Oman's Religious Tolerance: A Review of the Late 19th and Early 20th Century Ibadi Jurisprudence of Nūr al-Din al-Sālimi from Oman and Muhammad Ațayyash from North Africa Regarding Coexistence with Jews and Christians. In: B. Michalak-Pikulska and R. Eisner, eds., Ibadi Jurisprudence. Hildesheim: Olms, 195-209.

Lewicki, T., 1957. La répartition géographique des groupements ibāḍites dans l'Afrique du Nord au moyen-âge. Rocznik Orientalistyczny, 21, 301-43. 
Lewicki, T., 1960. Quelques extraits inédits relatifs aux voyages des commerçants et des missionnaires ibāḍites nord-africains au pays du Soudan occidental et central au moyen age. Folia Orientalia, 2, 1/2, 1-27.

Lewicki, T., 1962. L'état nord-africain de Tāhert et ses relations avec le Soudan occidental à la fin du VIIIle et au IXe siècle. Cahiers d'études africaines [online], 2(4/8), 513-35. Available from: https://doi.org/10.3406/cea.1962.3255 [Accessed 12 May 2020].

Lewicki, T., 1964. Traits d'histoire du commerce transsaharien. Marchands et missionnaires ibadites en Soudan occidental et central au cours des VIIIe-XIIe siècles. Etnografia polska, 8, 291-311.

Lewicki, T., 1971. al-Ibāḍiyya. Encyclopaedia of Islam (New Edition), vol. 3. Leiden: Brill, 648-60.

Lewinstein, K., 1991. The Azāriqa in Islamic Heresiography. Bulletin of the School of Oriental and African Studies [online], 54(2), 251-68. Available from: https://doi.org/10.1017/S0041977X00014774 [Accessed 12 May 2020].

Madelung, W., 2006. 'Abd Allāh ibn Ibāọ and the Origins of the Ibādiyya. In: B. Michalak-Pikulska and A. Pikulski, eds., Authority, Privacy and Public Order in Islam. Leuven: Peeters, 51-8.

al-Misri, A.H., 2000. Khawaarij \& Jihad, including a full chapter about the massacre in Algeria. Birmingham: Makhtabah al-Ansar, n.d. [2000].

Mu'ammar, 'A.Y., 2007. Ibādism in History. Volume 1: The Emergence of the Ibāḍ̄ School. Ruwi, Oman: Ministry of Awqaf and Religious Affairs.

Nāșir, M.S., 1980. Abū 'l-Yaqẓān wa-jihād al-kalima. Alger: al-Sharika al-wațanīya lilnashr wa'l-tawzī'.

Nāṣir, M.S., ed., 2002. Al-multaqāa al-awwal li-fikr al-imām al-shaykh Ibrāhīm b. 'Umar Bayyūụ. al-Qarāra: Jamī' at al-turāth.

Ourghi, A.H., 2006. Die Reformbewegung in der neuzeitlichen Ibādìya: Leben, 2006. Werk und Wirken von Muhmmad b. Yüsuf Attaiyaš, 1236-1332 h.q. (1821-1914). Ph.D. thesis. Albert-Ludwigs-Universität Freiburg.

Pouwels, R.L., 2002. Horn and Crescent: Cultural Change and Traditional Islam on the East African Coast, 800-1900. Cambridge University Press.

Prevost, V., 2010. Les Ibadites: De Djerba à Oman, la troisième voie de l'Islam. Turnhout: Brepols.

al-Rawas, I., 2000. Oman in early Islamic History. London: Ithaca.

Rebstock, U., 1983. Die Ibāditen im Maġrib (2./8.-4./10. Jh.): Die Geschichte einer Berberbewegung im Gewand des Islam. Berlin: Klaus Schwartz.

al-Salimi, A., 2017. Early Islamic Law in Basra in the 2nd/8th Century: Aqwal Qatadah b. Da'amah al-Sadusi. Leiden: Brill. Available from: https://doi.org/10.1163/9789004339538 [Accessed 12 May 2020]. 
Savage, E., 1997. A Gateway to Hell, a Gateway to Paradise: The North African Response to the Arab Conquest. Princeton: Darwin Press.

Schacht, J., 1950. The Origins of Muhammadan Jurisprudence. Oxford: Clarendon Press.

Shinar, P., 1961. Ibāḍiyya and orthodox reformism in modern Algeria. Studies in Islamic History and Civilzation, Scripta Hireosolymitana, 9, 97-120.

Siegfried, N.A., 2000. Legislation and Legitimation in Oman: The Basic Law. Islamic Law and Society [online], 7(3), 359-97. Available from: https://doi.org/10.1163/156851900507689 [Accessed 12 May 2020].

Ṭallāy, I.M., 1996. al-Ibāḍìya laysū min al-khawārij, n.p., n.d. [1996].

Vigourous, L., 1945. L'émigration mozabite dans les villes du Tell algérien. Travaux de l'Institut de recherches sahariennes, 3, 87-102.

Vikør, K.S., 1995. Sufi and Scholar on the Desert Edge: Muhammad b. 'Alī al-Sanūsī and his Brotherhood. London: Hurst.

Vikør, K.S., 1999. The Oasis of Salt. The History of Kawar, a Saharan Centre of Salt Production. Bergen: Centre for Middle Eastern Studies.

Wilkinson, J.C., 1985. Ibāḍi hadīth: an essay on normalization. Der Islam [online], 62(2), 231-59. Available from: https://doi.org/10.1515/islm.1985.62.2.231 [Accessed 12 May 2020].

Wilkinson, J.C., 1987. The Imamate Tradition of Oman. Cambridge University Press.

Wilkinson, J.C., 2010. Ibâḍism: Origins and early development in Oman. Oxford University Press.

Wilkinson, J.C., 2015. Moderation and Extremism in Early Ibāḍ̄i Thought. In: E. Francesca, ed., Ibadi Theology: Rereading Sources and Scholarly Works. Hildesheim: Olms, 47-53.

Ziaka, A., 2015. The Roots of the Ușūl al-Fiqh in the Ibādi Madhhab: A Comparison Between Abū Sa id al-Kudami and Ibn Baraka. In: B. Michalak-Pikulska and R. Eisner, eds., Ibadi Jurisprudence: Origins, Developments and Cases. Hildesheim: Olms, 93-100. 